\title{
Editorial
}

\section{Quem, onde, quando, o quê e o porquê}

\author{
Who, where, when, what and why?
}

Subordinado ao título acima, pôde-se ler interessante Editorial publicado em órgão da Academia de Ciências de Nova York, a respeito de hipóteses de trabalho científico para a poderosa nação norte-americana (Nichols $\left.{ }^{4}, 1995\right)$. Em que pese a nossa incipiência, frente àquele gigante onipotente, talvez coubesse fazer-nos a mesma pergunta. Em especial, no que tange ao campo das ciências biológicas aplicadas aos problemas de saúde que afligem a nossa população. Obviamente, sem ignorar o seu significado social. Ocorre que, neste texto e dentro do cenário de nosso estádio cultural, objetiva-se focalizar aquelas e as conseqüências de seus resultados.

Se o Brasil é País industrializado, ao menos em alguma medida (Schneider $\left.{ }^{6}, 1996\right)$, se tem contingente populacional apreciável (cerca de 160 milhões), se dispõe de recursos naturais exploráveis (e explorados) e se é dotado de agropecuária significante, nada impediria a formulação daquela questão no que concerne ao que produz no campo das ciências biológicas aplicadas à saúde. Não obstante, o nosso País tem de arcar com desvantagens para chegar a respondê-la de maneira satisfatória. Desvantagens essas decorrentes de sua inserção no assim chamado terceiro mundo. O que significa, em princípio, ser culturalmente colonizado e destinado, principalmente, a representar o papel de consumidor e assim obrigandose, direta ou indiretamente, a aceitar o que lhe é oferecido pela ciência e tecnologia do primeiro mundo. Ocorre que nem sempre tais produtos vão ao encontro dos interesses de sua população. Principalmente quando se trata de problemas nosológicos. Diante disso, convirá considerar como se responderia à pergunta que dá título ao presente texto, para país como o nosso.

Inicialmente, quem e onde. Se os resultados científicos forem aplicáveis à melhoria da qualidade de vida humana, é de se esperar que o investimento maior seja do Estado. E a fundo perdido, uma vez que os conhecimentos, assim adquiridos, contribuem para o crescimento cultural do país. Se porém, o produto cien- tífico irá se traduzir em artigo "vendável”, no sentido comercial do termo, então haveria de se esperar interesse por parte do setor empresarial da sociedade. Em vista disso, a tendência que se observa agora, em nosso meio, é a de envolver este nas atividades de pesquisa, claro está que de natureza tecnológica. Como exemplo eloqüente pode-se mencionar o entusiasmo atual com o possível estabelecimento de "parcerias" empresa-universidade. Isso significa que a ciência deveria apoiar a indústria e que as universidades deveriam objetivar o fornecimento de resultados de suas pesquisas que fossem utilizáveis por aquela. O que implica, por decorrência, administrar a universidade de maneira semelhante à empresa. Contudo, para tanto, há óbices evidentes e de caráter, salvo melhor juizo, intransponível.

Assim, o que se poderá prever em tais "parcerias" será a concentração das atividades científicas no campo da tecnologia. Mesmo dessa maneira, nem sempre o retorno econômico seria suficientemente rápido para compensar o investimento. A empresa, como entidade isolada, dificilmente poderia arcar com custos de investigações a longo prazo. Pode-se argumentar com exceções, se bem que nenhuma delas em países terceiromundistas, como o nosso. Tais são, o projeto Novartis e o do Genoma Humano. O primeiro tem por objetivo o desenvolvimento biotecnológico e químico de arsenal terapêutico com vistas a doenças crônicas e degenerativas, além de transplantes. Nele, encontram-se englobadas três grandes empresas multinacionais de produtos farmacêuticos, pretendendo levar avante as pesquisas em, de início, o que elas consideram seis centros de "excelência". Destes, três nos Estados Unidos da América do Norte (EUA), um na Inglaterra, um na Suiça e um na Austria (Koenig², 1996). O segundo, visa o mapeamento do Genoma Humano, com a identificação dos genes. Recentemente pôde-se divulgar resultado parcial que foi produzido, de maneira semi-industrial, por pesquisadores em cerca de vinte centros de investigação científica (Schuler e col. $\left.{ }^{7}, 1996\right)$. Obviamente, em que pese serem am- 
bos os projetos, de longa duração, têm o objetivo precípuo de alcançar os benefícios do poder econômico. Em decorrência, o tratamento e a prevenção das doenças humanas focalizadas estará ao alcance daquela parte da população do planeta que disponha de poder aquisitivo suficiente para tanto.

Se bem que a riqueza em recursos intelectuais da sociedade se concentre nas universidades, a aplicabilidade das pesquisas, ali realizadas, para a indústria, restringe-se praticamente ao desenvolvimento da instrumentação tecnológica como, por exemplo, nas áreas de engenharia, da química, da medicina e de outras. Por sua vez, cabem na universidade as atividades de pesquisa básica, sem o vislumbre de aplicabilidade a curto prazo, a não ser a relativa ao enriquecimento do saber humano, como, por exemplo, a literatura, a teoria dos números, a sistemática biológica e muitos outros campos do conhecimento. O que se espera da universidade, em matéria de pesquisa, é que seja núcleo de elaboração de idéias e de iniciativas (Mac Lane ${ }^{3}$, 1996). Pouco deveria interessar à sociedade, o montante de recursos oficiais nela investidos. Trata-se de investimento a longo prazo, medido em gerações futuras. Aqueles que a acusam de ser "saco sem fundos" orçamentário utilizam, para tanto, chavões que são repetidos com freqüência e que não deixam de causar alguma irritação, tais como o referente à necessidade de "perseguir resultados que vão ao encontro dos interesses nacionais", ou então, "se a universidade é sustentada pela sociedade, então deve ater-se ao que interessa a esta, caso contrário, aquela não deveria continuar a sustentála”. Esses são alguns exemplos de interpretação totalmente errada da universidade. Se é questão de "impactar" com suas descobertas científicas, como fazê-lo "a priori”"? Seria possível avaliar previamente o impacto dos estudos de estrutura do átomo ou da descoberta do DNA?

Outra feição da vida acadêmica que vai de encontro aos interesses empresariais, vem a ser o da estabilidade funcional. E isso em que pese a atual orientação governamental que, em consonância com a ética capitalista, confunde a prestação de serviços com investimentos. A estabilidade dos pesquisadores universitários permite-lhes levar a cabo estudos prolongados, às vezes neles dispondo todo o tempo de suas vidas. Além disso, protege-os das ingerências da politicagem. A existência de instituição à qual se deu o nome de Universidade é muito anterior à da Empresa. Aquela representa o processo de descobrir e de transmitir conhecimentos a gerações novas, e nela não cabe o modelo do "livre mercado" baseado na competição darwiniana.
No que concerne ao quando e ao $o$ quê, é de se convir que o nosso País deveria dispor-se, agora, a desenvolver sua própria atividade científica. Ao menos, no que respeita aos próprios problemas nosológicos que comprometem a qualidade de vida de sua população. Aliás, como já o fez por ocasião da primeira metade do presente século, descontinuada ou reduzida após a segunda guerra mundial. Nesse particular, o Brasil encontra-se atualmente em situação intermediária. Eis que, ao mesmo tempo, necessita de investir em educação, elementar e secundária, e dispõe de capacidade para a produção científica. Ainda mais, ao se atentar que esta não pode ser tida como luxo de nações do primeiro mundo. Qualquer país que almeje o desenvolvimento cultural, deve ter o propósito de investir em ciência e tecnologia. E ainda mais quando abriga múltiplos problemas de saúde, com os quais se vê a braços a sua população. Toda nação do terceiro mundo (dito, eufemisticamente, de "em desenvolvimento") necessita de reacender a sua atenção para a persistência e o ressurgimento de grandes problemas relativos às doenças infecciosas e endêmicas. Sem pesquisas de caráter fortemente autóctone, dificilmente tal problemática deixará de comprometer aquele citado desenvolvimento. Assim, pode-se citar, como exemplo, os ainda totalmente insuficientes investimentos em estudos sobre malária, esquistossomose, leishmanioses e, menos ainda, sobre biologia de seus vetores. Ao menos no que concerne à participação nacional. No momento mesmo em que estas linhas estão sendo redigidas ( 24 de novembro de 1996), o Senhor Presidente da República está encetando viagem de visita ao país de Angola, na África. Em decorrência, pôde-se ouvir pelo noticiário radiofônico, os múltiplos conselhos que lhe foram dados em relação a medidas preventivas, tais como, tomar drogas antimaláricas, evitar a ingestão de alimentos crus, deixar de sair ao ar livre em horários que coincidam com os de maior atividade anofelínea, ou seja, das 05:00 às 07:00 e das 18:00 às 20:00 horas. Isso talvez devesse motivar Sua Excelência para o significado dessas endemias. Mormente no que concerne à população de seu próprio País e, assim, servir de estímulo para propiciar meios de desenvolver pesquisas autóctones. Nesse particular, por exemplo, pouco adiantará gastar recursos e treinar nossa juventude em temas como o da supra referida pesquisa do Genoma Humano. A se insistir nesse campo da genética, melhor seria então que os projetos se voltassem para o estudo dos genomas de agentes infecciosos de endemias que assolam o território nacional. 
Ao leitor poderá configurar certa incongruência, das considerações acima, face ao que foi advogado em parágrafos anteriores a respeito da autonomia científica na universidade. Embora, em seu aspecto geral, tal aspecto autônomo faça parte dos "falsos dilemas" de Pellegrini Filho 5 (1994), há de se considerar que esse autor, como que se contradiz ao afirmar, ao mesmo tempo o papel do "mercado" social como definidor das prioridades, que dever-se-ia seguir o exemplo de países que fizeram da "ciência e tecnologia parte integral de seu desenvolvimento". Ora, este deve ser encarado como patrimônio cultural, em seu todo, e não apenas material, ou seja, econômico. E o avanço cultural sedia-se, precipuamente, na universidade. Claro está que o terceiro mundo se vê na contingência atual de importar, principalmente, tecnologia. Não obstante, é de se desejar que seja capaz de absorvê-la e de desenvolvê-la de acordo com seus próprios meios.

Finalmente, resta considerar o porquê. Nas explanações feitas em parágrafos precedentes, pôde-se entrever a motivação que deveria estimular a aplicação de recursos no desenvolvimento científico do terceiro mundo. Constitui característica do ser humano, a de ansiar por conhecer o mundo que o cerca, quanto mais não seja, para se diferenciar dos antropóides, seus primos na escala evolutiva. Porém, tal curiosidade inata não mais se tornou suficiente. Há até algum tempo, a atividade de pesquisa científica outorgava, a quem a exercia, feição de confiabilidade e de elevado altruismo. Isso devia-se ao fato da ciência ter adquirido essa imagem em virtude da procura da verdade e de ter, por objetivo primordial, o benefício de toda a humanidade. Recentemente, porém, surgiram evidências de mudanças nessa conceituação. Assim, têm-se levantado questões sobre o caráter excessivamente sigiloso dos resultados alcançados como, por exemplo, nas pesquisas médicas que poderiam ensejar tratamentos e soluções para problemas de saúde e, pois, mitigar o sofrimento das pessoas afetadas por várias doenças. Contudo, com a mercantilização da ciência, isto é, com a transformação do dado científico em produto passível de comercialização, a urgência em divulgá-lo vem sendo paulatinamente substituída pela urgência em patenteá-lo. Na medida em que a empresa particular investe, esse aspecto torna-se cada vez mais acentuado. Nos EUA, o problema está se tornando preocupante face a exigências contratuais que dão às empresas a propriedade dos resultados da pesquisa, inclusive o direito de divulgá-los ou não (Gibbs ${ }^{1}$, 1996). Têm ocorrido exemplos evidentes dessa problemática, mormente na pesquisa genética com a caracterização e o isolamento de genes, potencialmente produtores de substâncias comercializáveis. Se isso ocorre na nação que é atualmente a líder mundial da pesquisa em ciência e tecnologia, imagine-se o que poderia ocorrer em nosso meio. No entanto, e a bem da verdade, há de se convir que a problemática análoga seria improvável que ocorresse no estado atual de nosso desenvolvimento científico. Pela simples razão da inexistência deste. Em outras palavras, a confirmar o colonialismo cultural ao qual estamos sujeitos, não se poderá vislumbrar qualquer possibilidade de competição (no bom sentido) em determinados campos de investigação como, por exemplo, o da biologia molecular. Neste, restar-nos-á o papel de copistas. Na melhor das hipóteses, de mão-de-obra menos dispendiosa, para servir tecnicamente às grandes pesquisas multinacionais. Isso assemelha-se, "mutatis mutandi", ao que se presencia com a indústria automobilística, assim dita, "nacional".

Não obstante, existem campos que poderão (e necessitarão) abrigar a ciência autóctone. E até porque eles deixaram de interessar àqueles países que são os donos incontestes dos outros campos. Na área da saúde, trata-se, como já se referiu, da nosologia concernente às endemias que assolam a nossa população, em particular, e as da América Latina, em geral. Seria pois de todo aconselhável que se investisse e se estimulasse a procura de soluções, abordando os vários aspectos de tais problemas. Os resultados obtidos deveriam ser prioritariamente divulgados, de maneira acessível, nos meios centro e sul-americanos. Os nossos pesquisadores deveriam valorizar menos a "internacionalização" e mais a "americalatinização", se assim se pode chamar, das informações obtidas e das suas decorrentes reputações científicas. Os poderes governamentais deveriam interessar-se mais em estimular a nossa juventude em relação a essas pesquisas. Eis que estas, embora acoimadas, por muitos, de "subdesenvolvidas", são de indiscutível utilidade para a nossa tão "subdesenvolvida" população. Salvo melhor juízo, afigura-se ser esse o melhor caminho que a atividade científica da América Latina deve, "in primo loco", dispor-se a seguir. Se é que realmente almeja tornar-se independente e livre.

Oswaldo Paulo Forattini Editor Científico 


\section{REFERÊNCIAS BIBLIOGRÁFICAS}

1. GIBBS, W.W. The price of silence. Scient. Amer, 275:10-2, 1996.

2. KOENIG, R. Giant merger creates biotech power. Science, 271:1490, 1996.

3. MAC LANE, S. Should universities imitate industry? Amer. Scient., 84:520-1, 1996.

4. NICHOLS, R.W. Who, where, when, what and why? The Sciences, 35:4, 1995.
5. PELLEGRINI FILHO, A. A basis for the formulation of policies on health science and technology in Latin America. Bull. PAHO, 28:331-43, 1994.

6. SCHNEIDER, R.M. Brazil: culture and politcs in a new industrial powerhouse. Boulder, Colorado, Westview Press, Inc., 1996.

7. SCHULER, G.D. et al. A gene map of the human genome. Science, 274:540-6, 1996. 